\title{
Pembinaan Literasi Membaca melalui Self Motivation sebagai Upaya Mengembangkan Life Skill dan Meningkatkan Hasil Belajar pada Anak Usia Sekolah Dasar
}

\author{
Yohamintin'1 , Yosi Gumala ${ }^{2}$,Vira Pratiwi ${ }^{3}$,Awiria ${ }^{4}$ \\ ${ }_{1234}$ Universitas Bhayangkara Jakarta Raya \\ email:1yohamintin@dsn.ubharajaya.ac.id, 2yosi.gumala@dsn.ubharajaya.ac.id,

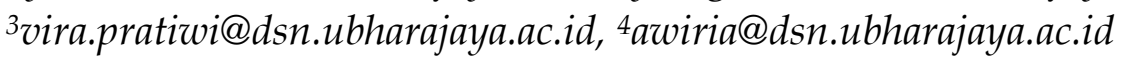

\begin{abstract}
Abstrak
Pengabdian masyarakat yang dilaksanakan dilatarbelakangi oleh rendahnya peringkat literasi Indonesia dan rendahnya kemampuan membaca peserta didik Indonesia di dunia Internasional berdasarkan data yang dirilis oleh World's Most Literate Nations, dan Progres in International Reading Literacy Study. Sebagai bentuk nyata kegiatan pengabdian pada masyarakat maka dilaksanakan sebuah kegiatan training yang bertujuan untuk menumbukan motivasi diri pada peserta didik dalam meningkatkan minat dan kemampuan membaca. Kegiatan ini bertema "Self Motivation Sebagai Upaya untuk Mengembangkan Life Skill dan Meningkatkan Hasil Belajar pada Anak Usia Sekolah Dasar" di Teluk Pucung Bekasi, yang berdasarkan observasi pendahuluan didapatkan masih kurang dalam literasi. Metode kegiatan Pengabdian kepada Masyarakat ( $\mathrm{PkM}$ ) ini menggunakan metode ceramah dan pelatihan ini sekaligus menjadi media bagi dosen di program studi pendidikan dasar untuk mensosialisasikan dan mendesiminasikan hasil-hasil penelitian dalam bidang literasi untuk lebih dapat diaplikasikan secara langsung di sekolah dasar mitra. Hasil dari pelaksanaan PkM ini didapatkan adanya respon motivasi belajar yang semakin baik, yang ditunjukan oleh peningkatan nilai yang diperoleh dari hasil pre test dan post test dalam pemahaman konsep sains. Dampak positif dari pelatihan dengan mengoptimalkan digital literasi ini mendorong berkembangnya kecakapan hidup peserta didik dalam mengembangkan potensi diri dan lebih bijak dalam menggunakan media digital. Sehingga dapat disimpulkan bahwa penggunaan digital literasi yang tepat dan ditanamkan sejak usia sekolah dasar, dapat memunculkan keterampilan hidup dan meningkatkan self motivation pada peserta didik yang akan meningkatkan hasil belajar.
\end{abstract}

Kata Kunci: Literasi membaca, Self Motivation, peserta didik SD, hasil belajar

\begin{abstract}
The community service that is carried out is motivated by the low level of Indonesian literacy and the low reading ability of Indonesian students in the international world based on data released by the World's Most Literate Nations, and the Progress in International Reading Literacy Study. As a tangible form of community service activities, a training activity is carried out which aims to foster self-motivation in students in increasing their reading interest and
\end{abstract}


ability. This activity has the theme "Self Motivation as an Effort to Develop Life Skills and Improve Learning Outcomes in Elementary School Age Children" in Teluk Pucung Bekasi, which based on preliminary observations it is found that there is still a lack of literacy. This training is also a medium for lecturers in the basic education study program to socialize and disseminate research results in the field of literacy so that they can be applied directly to partner primary schools. By increasing the value obtained from the results of the pre-test and post-test in understanding the concept of science. The positive impact of this training by optimizing digital literacy encourages the development of life skills of students in developing self-potential and wiser in using digital media. So it can be concluded that the proper use of digital literacy and instilled since elementary school age, can bring out life skills and increase self-motivation in students which will improve learning outcomes.

Keywords: Literacy reading, Self Motivation, elementary students, Learning outcomes

\section{Pendahuluan}

World's Most Literate Nations telah melakukan pemeringkatan terbaru menurut data yang disusun oleh Central Connecticut State University tahun 2016, tentang literasi Indonesia berada di posisi kedua terbawah dari 61 negara yang diteliti (Agoestyowati, 2017). Indonesia hanya lebih baik dari Bostwana, negara di kawasan selatan Afrika. Fakta ini didasarkan pada studi deskriptif dengan menguji sejumlah aspek. Antara lain, yang mencakup 5 kategori, yaitu: perpustakaan, koran, input sistem pendidikan, output sistem pendidikan, dan ketersediaan komputer. Data yang bersumber dari kelima data tersebut menunjukkan bahwa kondisi minat baca bangsa Indonesia memang cukup memprihatinkan.

Berdasarkan kajian empiris yang telah dilakukan bahwa kemampuan membaca pelajar Indonesia di dunia Internasional masih lemah. Hal tersebut berdasarkan tes yang dilakukan oleh Progres in International Reading Literacy Study (PIRLS) tahun 2011. Dengan hasil yakni, hampir semua butir soal belum dapat dijawab dengan indikator pengukuran pada hasil membaca teks sastra dan teks informasi peserta didik kelas 4 Sekolah Dasar. (PIRLS International Report, 2011)

Literasi membaca yang terfokus pada membaca pemahaman mencakup empat kajian utama, yaitu: (1) keterampilan membaca; (2) penerapan, pelatihan, dan penetapan bacaan; (3) proses membaca; dan (4) teks yang digunakan dalam membaca (UNESCO, 2005) Adanya keterpenuhan fasilitas teks bacaan maupun informasi serupa mampu mengarahkan prestasi peserta didik dalam literasi membaca kearah yang lebih baik (Geske, A.\& Ozola, 2008). Literasi harus memenuhi indikator; keberadaan, kontekstual, akibatnya, relatif, dan terikat budaya. Literasi haruslah mencakup berbagai lini kehidupan manusia dalam banyak hal (Baleiro, 2011).

Self Motivation merupakan hal yang sangat penting dalam kehidupan sehari-hari. Seseorang mampu menggunakan potensi dirinya secara optimal bila memiliki motivasi yang tinggi. Motivasi merupakan suatu dorongan yang timbul karena adanya rangsangan dari dalam maupun dari luar, sehingga seseorang berkeinginan 
untuk mengadakan perubahan tingkah laku agar lebih baik (Purwanto, 2013). Dan dengan memperbaiki motivasi diri peserta didik dengan literasi bacaan-bacaan yang mendidik merupakan suatu jawaban akan solusi peningkatan minat dan hasil belajar pelajar Indonesia.

SDN Harapan Baru 2 Bekasi Utara merupakan sekolah dasar binaan dibawah naungan program studi PGSD Universitas Bhayangkara Jakarta Raya. Berdasarkan studi pendahuluan yang dilakukan tim peneliti PkM ini, ditemukan kondisi dilapangan beberapa masalah dalam proses penunjang kegiatan belajar mengajar. Beberapa masalah seperti: peningkatan jumlah karya ilmiah yang masih rendah pada guru yang berdampak secara tidak langsung pada kualitas pengajaran, fasilitas pendukung literasi yang masih minim, dan relatif rendahnya tingkat budaya literasi pada peserta didik. Dimana hal ini dapat menjadi indikator dalam proses pembelajaran dan peningkatan mutu pendidikan di sekolah.

Berdasarkan permasalahan yang telah dikemukakan, perlu dilakukan program pembinaan dan pembiasaan untuk meningkatkan kebiasaan dalam membaca. Salah satu solusi yang dapat dilakukan untuk meningkatkan literasi membaca peserta didik dalam mengembangkan life skills adalah dengan pembinaan literasi membaca dan meningkatkan motivasi diri yang pada akhirnya dapat meningkatkan life skills peserta didik.

\section{Metode}

Metode kegiatan Pengabdian kepada Masyarakat (PkM) ini menggunakan metode ceramah, pelatihan dan simulasi. Pelatihan (training) adalah suatu proses pendidikan jangka pendek yang mempergunakan prosedur sistematis dan terorganisir untuk mempelajari pengetahuan dan keterampilan teknis dalam tujuan terbatas (Sikula Andrew E, 2011). Pelatihan ini dilakukan pada anak- anak sekolah dasar di wilayah Teluk Pucung, tepatnya di SDN Harapan Baru 2 Bekasi Utara, dengan jumlah peserta sebanyak 30 peserta didik yang kesemuanya merupakan peserta didik kelas V. Penilaian capaian PKM ini menggunakan instrument, berupa soal pretest dan post test yang dibagikan sebelum dan sesudah kegiatan.

Penilaian dilakukan untuk mengukur capaian PkM pembinaan literasi digital yang berdampak pada motivasi belajar, yang dilihat dari peningkatan hasil belajar peserta didik, baik dalam proses pembelajaran maupun hasil tes sebagai indikator ketercapaian. Score dari instrument dianalisa peningkatannya dan dipersentasekan. Hasil dari serangkaian kegiatan ini yaitu peningkatkan pemahaman peserta didik yang dilihat dari tes yang merupakan indikator peningkatan life skill dengan literasi membaca.

\section{Hasil dan Pembahasan}

Sekolah Dasar Negeri Harapan Baru 2 merupakan salah satu sekolah dasar yang berada di Bekasi utara yang beralamat di Jl. Perjuangan No. 29 Kecamatan Bekasi 
Utara Kota Bekasi 17123. Sekolah ini didirikan pada 1 April 1982 dan memiliki luas $1930 \mathrm{~m}^{2}$. Sekolah aktif dalam berbagai kegiatan baik tingkat gugus maupun kecamatan. SDN Harapan Baru 2 memiliki berbagai kegiatan ekstrakurikuler yang mampu mengembangkan life skill peserta didik, diantaranya; bela diri, pramuka, seni drama dan beberapa ekstrakurikuler lainnya. Namun, sekolah ini belum memiliki ruang perpustakaan layak dan aktif yang dapat digunakan secara leluasa oleh peserta didik. Disisi lain, tidak menyerah pada kondisi perpustakaan yang belum masif, terdapat insiatif salah seorang guru kelas yang mendesain pojok kelas menjadi pojok baca. Gambar 1 adalah potret pojok baca sebagai bentuk kreatifitas guru dan peserta didik yang terdapat di SDN Harapan Baru 2.

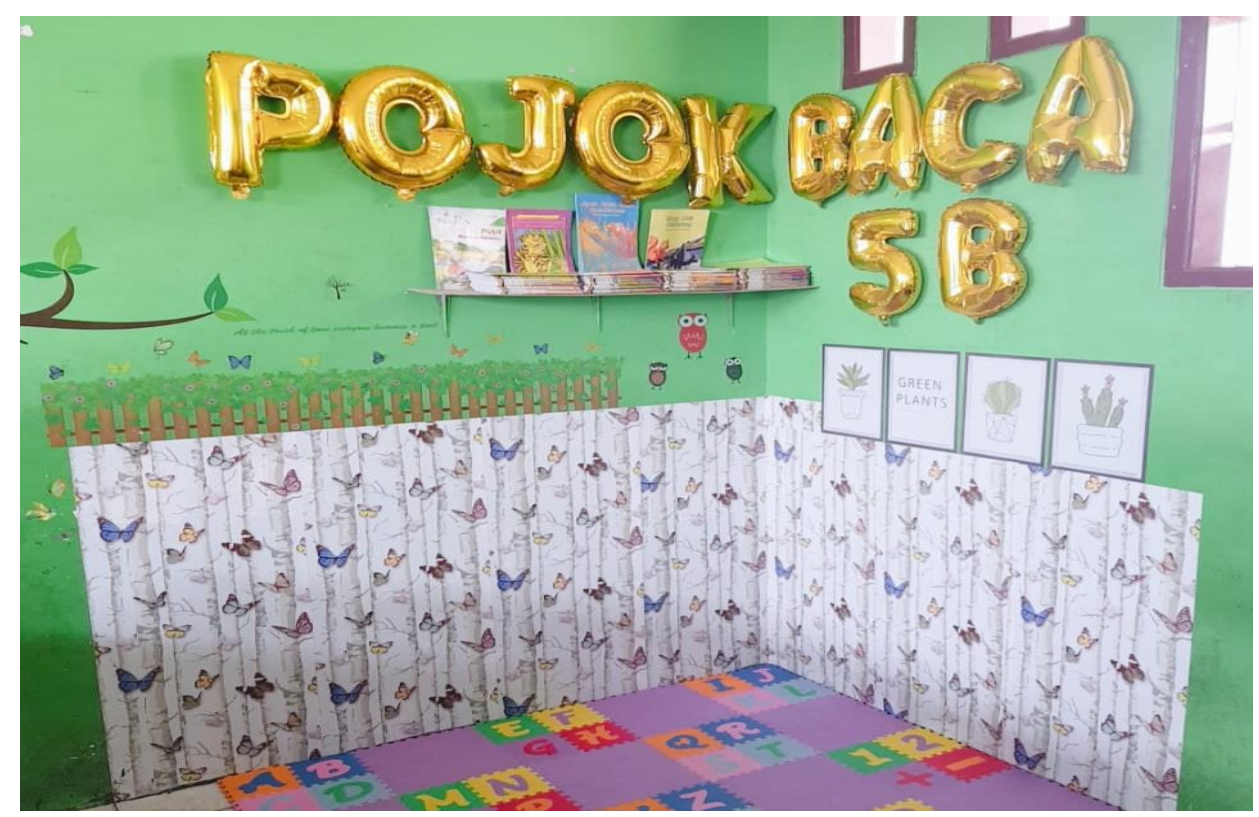

Gambar.1. Pojok Baca SDN Harapan Baru 2

Salah satu insiatif guru tersebut dapat menjadi sumber inspirasi bagi peserta didik agar mengikuti jejak gurunya. Disisi lain masih banyak potensi yang dapat digali di sekolah tersebut. Hal ini lah yang menjadi alasan mengapa sekolah ini menjadi mitra dalam kegiatan pengabdian masyarakat dengan tema "Pembinaan Literasi Membaca Melalui Pelatihan Self Motivation sebagai Upaya untuk Mengembangkan Life Skill pada Anak Usia Sekolah Dasar.

Adanya masalah dalam peningkatan mutu pendidikan menjadi hal penting harus diperhatikan dan dicarikan solusi terbaik. Salah satu upaya sebagai praktisi pendidikan yakni melakukan tanggungjawab pelaksanaan tridarma perguruan tinggi dalam perbaikan mutu pendidikan. Pelaksanaan pengabdian ini dilakukan di SDN Harapan Baru 2 Bekasi Utara, dengan jumlah peserta sebanyak 30 peserta didik yang kesemuanya merupakan peserta didik kelas V.

Berikut data hasil pengambilan nilai pretest (gambar 2) dan posttest (gambar 3) pada salah satu materi pelatihan pembinaan digital literasi, mengenai Pemahaman Konsep Sains yang diambil dari 30 peserta didik kelas V sekolah dasar. 


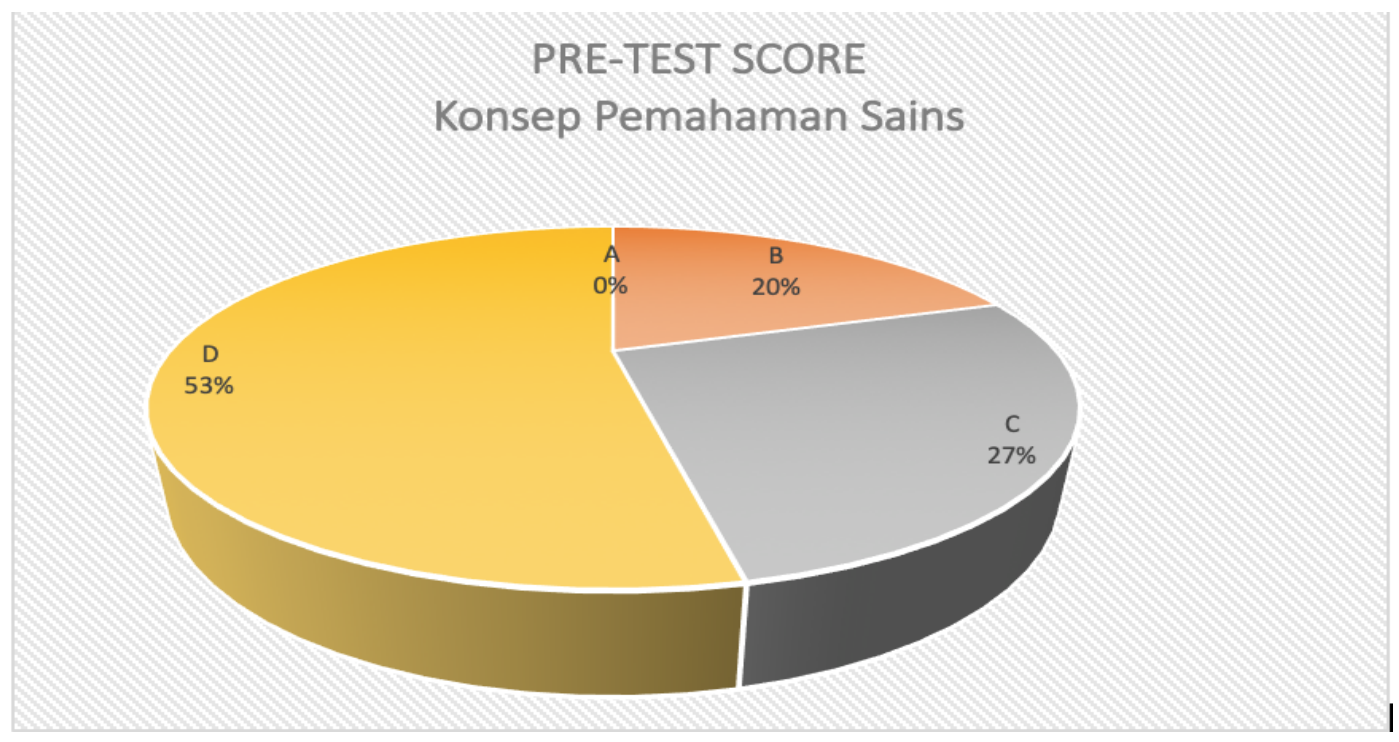

Gambar.2. Persentase Nilai pretest peserta didik pada Pemahaman Konsep Sains (dengan rentang predikat nilai rentang A hingga D)

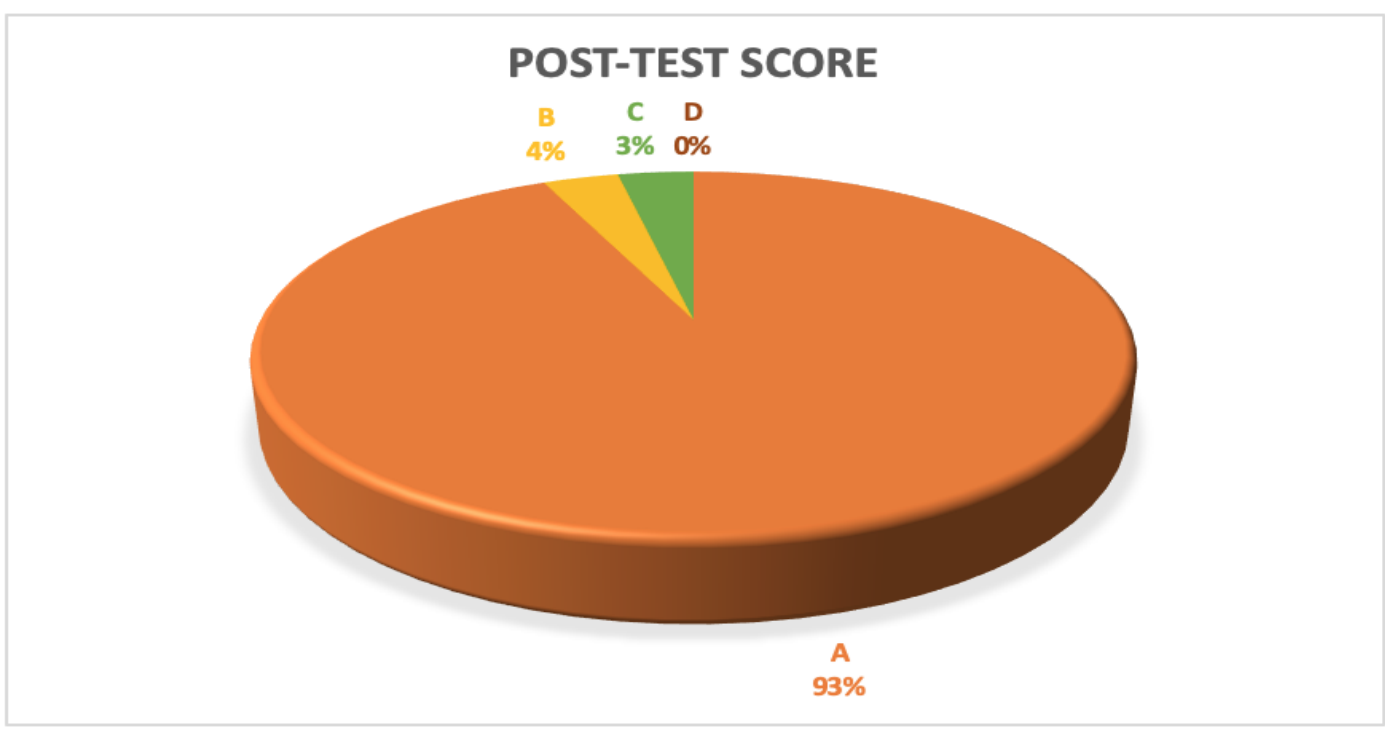

Gambar.3. Persentase Nilai posttest peserta didik pada Pemahaman Konsep Sains (dengan rentang predikat nilai rentang A hingga D)

Presentase pada diagram di atas menggunakan rentang penilaian dengan ketuntasan nilai 60 (Kemendikbud, 2016), dengan keterangan sebagai berikut:

\begin{tabular}{|r|c|c|c|c|c|}
\hline \multirow{2}{*}{$\begin{array}{c}\text { KKM Satuan } \\
\text { Pendidikan }\end{array}$} & Panjang & \multicolumn{4}{|c|}{ RENTANG PREDIKAT } \\
\cline { 3 - 6 } & Interval & $\begin{array}{c}\mathrm{A} \\
(\text { Sangat Baik })\end{array}$ & $\begin{array}{c}\mathrm{B} \\
(\text { Baik })\end{array}$ & $\begin{array}{c}\mathrm{C} \\
(\text { Cukup })\end{array}$ & $\begin{array}{c}\text { D (Perlu } \\
\text { Bimbingan) }\end{array}$ \\
\hline 60 & $40 / 3=13,3$ & $87<\mathrm{A} \leq 100$ & $73<\mathrm{B} \leq 87$ & $60<\mathrm{C} \leq 73$ & $\mathrm{D}<60$ \\
\hline
\end{tabular}

Tabel. 1. Interval Penilaian yang digunakan untuk presentase nilai tes 
Sebelum kegiatan dilakukan mengambilan data nilai pretest, sebagai tolak ukur keberhasilan kegiatan (lihat gambar 2). Ditemukan masih banyak peserta didik yang memiliki nilai dibawah 60 dengan persentase 53\% yakni 16 peserta didik yang memperoleh nilai 60 dari 30 peserta didik dengan penilaian di rentang predikat D dan membutuhkan bimbingan lebih lanjut. Di rentang predikat $C$ sebesar $27 \%$ dengan penilaian cukup, yang diperoleh dari 8 peserta didik. Di rentang predikat sebesar 20 $\%$ dengan penilaian baik, yang diperoleh dari 6 peserta didik. Sedangkan untuk rentang predikat A dengan penilaian sangat baik tidak ada. Pembelajaran yang dilakukan oleh guru kelas sebelumnya kurang variatif, kemungkinan disebabkan oleh keterbatasan fasilitas pembelajaran maupun inovasi pembelajaran di sekolah yang kurang mendukung. Kegiatan pembelajaran seringnya menggunakan metode ceramah di kelas yang heterogen dengan jumlah peserta didik yang cukup banyak. Sahyodi (2020) dalam penelitiannya mengungkapkan bahwa banyaknya permasalahan ketidaktuntasan nilai minimal salahsatunya disebabkan metode pembelajaran yang kurang variatif, hanya mengandalkan metode ceramah dan mencatat serta kurang optimalnya penggunaan media belajar.

Setelah rangkaian pelaksanaan PkM diperoleh nilai post test pada rentang predikat $\mathrm{A}$ dengan persentase $93 \%$, rentang predikat nilai B sebesar $4 \%$, rentang predikat nilai C sebesar $3 \%$, dan tidak ada peserta didik yang memperoleh nilai di rentang predikat $\mathrm{D}$ (lihat gambar 3). Pentingnya inovasi yakni salah satunya adalah penggunaan optimal dari media belajar digital menjadi hal urgent yang harus dilakukan guru, dimana hal tersebut dapat membuat bangsa Indonesia mengejar ketinggalan pengetahuan akibat kemajuan teknologi demi meningkatkan life skill peserta didik (Nasution, 2017). Sebagaimana Prasasti (2019), dalam penelitiannya mengungkapkan bahwa penggunaan media digital yang menggantikan media konvensional merupakan salah satu alternatif untuk mengoptimalkan pendidikan, dimana penggunaan media digital yang inovatif dan game digital terbukti mempengaruhi perkembangan peserta didik contohnya dalam berpikir kritis.

Kegiatan ini diharapkan dapat continue dan menjadi salahsatu solusi peningkatan minat membaca anak-anak Indonesia, khususnya pada peserta didik di SDN Harapan Baru 2 Bekasi Utara, dengan memanfaatkan literasi digital yang dikemas dengan apik dan menyenangkan bagi peserta didik sehingga menstimulasi minat belajar peserta didik yang pada akhirnya berdampak pada peningkatan hasil belajar peserta didik. Pada saat kegiatan berlangsung terlihat antusiasme peserta didik dalam mengikuti rangkaian kegiatan, dan feedback positif peserta didik dalam bertanya dan merespon kegiatan diskusi.

Peserta didik yang mengikuti kegiatan pelatihan ini, merupakan peserta didik dari sekolah binaan program studi PGSD Universitas Bhayangkara Jakarta Raya. Salah satu Sekolah binaan prodi PGSD yakni SDN Harapan Baru 2 Bekasi Utara. Peserta pelatihan adalah peserta didik kelas $\mathrm{V}$ sekolah dasar yang dipilih karena kesuaian karakteristik peserta didik dengan materi pelatihan yang akan disampaikan. Jumlah peserta sebanyak 30 peserta didik, dengan durasi waktu pelaksanaan selama 2 hari. 
Berikut rundown acara pelatihan yang dilaksanakan pada 11-12 November 2019 (tabel 2)

Tabel. 2. Rundown kegiatan pelatihan

\begin{tabular}{|c|c|}
\hline Hari Pertama & $\begin{array}{l}\text { 1. Pembukaan oleh Dinas Terkait dan Tokoh Masyarakat } \\
\text { 2. Pembentukan Suasana } \\
\text { 3. Penyampaian materi IPA menggunakan digital literasi } \\
\text { 4. Games anak }\end{array}$ \\
\hline Hari Kedua & $\begin{array}{l}\text { 1. Penyampaian materi tentang manfaat membaca } \\
\text { 2. Brain storming "Self Motivation" } \\
\text { 3. Menyampaikan daftar bacaan yang membangun motivasi } \\
\text { 4. Mengajak anak-anak membuat daftar cita-cita } \\
\text { 5. Mengajak anak memanaje prestasi akademik } \\
\text { 6. Mengajak anak memanaje aktivitas ibadah } \\
\text { 7. Mengajak anak mengenal dan memelihara hobi } \\
\text { 8. Mengajak anak mengembangkan potensi diri } \\
\text { 9. Memahamkan anak pentingnya motivasi diri dan } \\
\text { 10. Penutupan oleh Dinas Terkait dan Tokoh Masyarakat }\end{array}$ \\
\hline
\end{tabular}

Pada hari pertama pelatihan peserta didik mendapatkan materi pemahaman konsep IPA dengan metode digital literasi dalam penyampaian, peserta didik diberikan pretest sebagai permulaan kegiatan. Diberikan icebreaking disetiap jeda sesi kegiatan dengan games menarik yang bertemakan literasi. Peserta didik diberikan manfaat membaca dan dibimbing agar lebih bijak dalam memilih bahan bacaan yang diperoleh dari digital/gagdet/internet.

Rangkaian kegiatan selanjutnya, peserta didik diberikan materi mengenai motivasi untuk mengembangkan diri, agar lebih semangat dalam belajar. Peserta didik dibimbing serta di informasikan daftar bacaan serta sumber yang bisa di akses, serta mengarahkan peserta didik untuk membuat target daftar bacaannya sendiri. Selanjutnya peserta didik diberikan arahan untuk; merenung dan membuat daftar cita-cita, memanaje prestasi akademik disekolah, memanaje aktivitas ibadah agar seimbang dengan belajar dan bermain, mengenalkan hobi yang bermanfaat, mengarahkan peserta didik untuk mengembangkan potensi diri, serta memahamkan anak pentingnya motivasi diri dan merencanakan hidupnya.

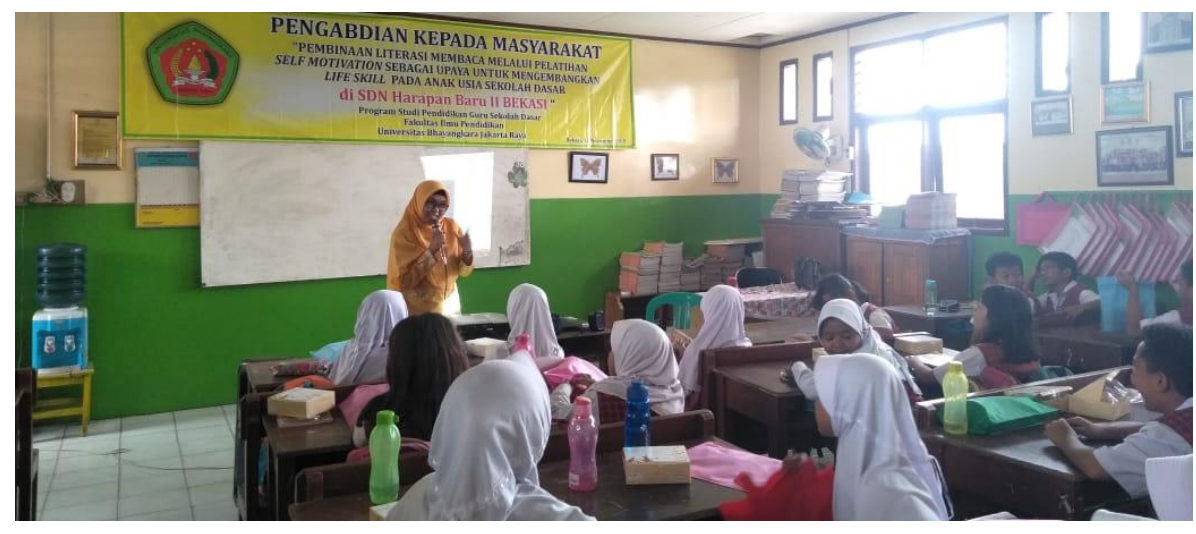

Gambar.3. Foto kegiatan PKM bersama peserta dan dosen PGSD 
Motivasi belajar urgent dalam mendukung keberhasilan kegiatan belajar mengajar. Motivasi selayaknya pemicu dalam kegiatan belajar, sehingga dengan semangat belajar yang maksimal akan tercapai keberhasilan. Pada PkM ini, respon motivasi belajar dinilai selama proses pembelajaran dimana indikatornya adalah feedback positif peserta didik dalam menyampaikan hasrat, impian, cita-cita, harapan masa depan yang diungkapkan secara verbal oleh ke 30 peserta didik. Sebagaimana pendapat (Sardiman, 2020) bahwa motivasi belajar yang baik akan mengiring kepada tingkah laku dan keberhasilan yang menjadi tujuan. Motivasi berperan penting agar tercapainya tujuan belajar optimal, dimana motivasi tidak semata mata muncul sendirinya. Peran guru dalam membangkitkan motivasi belajar peserta didik menjadi salah satu point penting bagi peserta didik sukses dalam meraih target belajarnya (Emda, 2017).

Merujuk kepada hal yang dikemukakan di atas, pemilihan pelatihan motivasi belajar untuk anak usia sekolah menjadi salah satu hal bermakna yang harus terus berlanjut. Pelatihan ini mengajak peserta didik yakni anak sekolah dasar khususnya untuk lebih cerdas dalam memilah bacaan digital dan memberikan motivasi, baik itu yang berasal dari internal peserta didik maupun eksternal peserta didik. Impuls untuk memunculkan motivasi internal dilakukan dengan perenungan cita- cita peserta didik. Sedangkan motivasi eksternal dapat berasal dari keluarga, guru, ataupun lingkungannya.

Adapun manfaat kegiatan pengabdian masyarakat secara umum adalah untuk menumbuhkan motivasi diri pada peserta didik. Motivasi dikhususkan dalam meningkatkan minat dan kemampuan membaca. Kegiatan ini menjadi media bagi para dosen di program studi pendidikan dasar untuk mensosialisasikan dan mendesiminasikan hasil-hasil penelitian dalam bidang literasi untuk lebih dapat diaplikasikan secara langsung di sekolah dasar.

Sebagai praktisi pendidikan tim dosen PkM Prodi PGSD Universitas Bhayangkara Jakarta Raya, menyadari bahwa literasi digital merupakan salah satu alat penting yang harus dikuasai oleh pemuda bangsa. Dengan harapan hal ini dapat membentuk skill peserta didik dalam berpikir kritis, analitis, kreatif, dan inovatif. Semua hal tersebut membutuhkan dukungan semua stake holders untuk membina generasi bangsa untuk memiliki motivasi belajar baik dengan arah tujuan benar, yang pada akhirnya akan berdampak pada tercapainya tujuan pendidikan nasional.

\section{Simpulan dan Rekomendasi}

Adanya peningkatan hasil belajar dan dorongan motivasi diri yang meningkat dilihat dari PkM diperoleh nilai posttest pada rentang predikat A dengan persentase $93 \%$, rentang predikat nilai $B$ sebesar $4 \%$, rentang predikat nilai $C$ sebesar $3 \%$, dan tidak ada peserta didik yang memperoleh nilai di rentang predikat $D$. Setelah melaksanakan program pengabdian masyarakat ini dengan judul "Pembinaan Literasi Membaca Melalui Pelatihan "Self Motivation" Sebagai Upaya Untuk Mengembangkan Life Skil dan Meningkatkan Hasil Belajar pada Anak Usia Sekolah Dasar Di SDN Harapan Baru 2 Bekasi 
Utara, akan kami melakukan evaluasi dari proses pelaksanaan dan pada temuantemuan yang kami peroleh selama pengabdian masyarakat, dapat kami simpulkan bahwa program pengabdian masyarakat sebagai salah satu wujud dari pelaksanaan tridharma perguruan tinggi ini telah mampu memberikan manfaat bagi anak sekolah dasar yang masih minim literasi dan kurang dalam motivasi untuk mengembangkan diri. Bentuk pelatihan seperti ini menjadi salah satu cara yang efektif untuk memberikan penyegaran dan wawasan baru di bidang pengembangan literasi bagi anak usia sekolah dasar, yang tentunya sangat membutuhkan seluruh pihak terkait yang membantu melancarkan kegiatan pengabdian kepada masyarakat.

Berdasarkan hasil evaluasi respon yang telah dilakukan, kami menyarankan hendaknya program-program pengabdian masyarakat ini dilaksanakan secara berlanjut dan terus menerus, melihat tingkat kebutuhan pengembangan life skill yang masih butuh pengembangan sehingga kelak masyarakat Indonesia, khususnya anak Indonesia agar memiliki kecakapan hidup yang lebih baik.

\section{Penghargaan}

Saya ingin mengucapkan terima kasih atas dukungan lembaga-lembaga berikut dalam pelaksanaan PkM ini. Terima kasih kepada Universitas Bhayangkara Jakarta Raya atas semua dukungannya. Dan juga terima kasih kepada SDN Harapan Baru 2, Bekasi Utara untuk memberikan tempat selama pembinaan dan untuk semua dukungan untuk menyelesaikan PkM ini.

\section{Daftar Pustaka}

Agoestyowati, R. (2017). Tinjauan pada Minat Literasi Anak-anak. Majalah Ilmiah Institut STIAMI, (1) 14.

Baleiro, R. (2011). A Definition of Literary Literacy: A Content Analysis of Literature Syllabuses and Inter-views with Portuguese Lecturers of Literature. Journal of New Horizons in Education.

Emda, A. (2017). Kedudukan Motivasi Belajar Siswa dalam Pembelajaran. Lantanida Journal, Vol. 5 No., 93-196.

Geske, A.\& Ozola, A. (2008). Factors Influencing Reading Literacy at The Primary School Level. Journal Problems of Education in The 21st Century, (6) 1.

Kemendikbud. (2016). Panduan Penilaian Untuk Sekolah Dasar. Jakarta: Ditjen Dikdasmen Kemendikbud.

Nasution, N. (2017). INOVASI KEMAMPUAN GURU DALAM KEGIATAN BELAJAR MENGAJAR DI SEKOLAH DASAR. Medan: Seminar Nasional Tahunan Fakultas Ilmu Sosial Universitas Negeri Medan.

PIRLS International Report. (2011). International Benchmarks TIMMS \& PIRLS Report International Study Center (IEA). 
Prasasti, A. K. (2019). Pemanfaatan Permainan Digital sebagai Sarana Edukasi Kesehatan Bagi Anak Usia Sekolah. Jurnal Keperawatan Florence, vol 4. No.

Purwanto. (2013). Motivasi belajar dalam pendidikan Islam. Jurnal Ilmu Tarbiyah "AtTajdid," 2(2), 221-236.

Sahyodi, I. (2020). Perbedaan Hasil Belajar Siswa Yang Menggunakan Metode Amsal Dengan Konvensional Pada Pembelajaran Pendidikan Agama Islam Di Kelas IV Sekolah Dasar Negeri 70 Bengkulu Tengah. IAIN BENGKULU.

Sardiman, A. (2020). Integrasi dan Motivasi Belajar. Jakarta: PT Raja Grafindo Persada.

Sikula Andrew E. (2011). Manajemen Sumber Daya Manusia (3rd ed). Bandung: Erlangga.

UNESCO. (2005). Literacy for Life. Paris (Prancis): United Nations Educational, Scientific, and Cultural Organization. 